\title{
Construction of a Shuttle Vector for Inducible Gene Expression in Escherichia coli and Bacillus subtilis
}

\author{
By HEINRICH LEONHARDT AND JUAN C. ALONSO* \\ Max-Planck-Institut für Molekulare Genetik, Ihnestr. 73, D-1000 Berlin 33, FRG
}

(Received 4 August 1987; revised 13 November 1987)

The construction of a shuttle vector for inducible gene expression allowing fast and easy cloning in Escherichia coli and subsequent transformation of Bacillus subtilis is presented. The expression is based on the regulation of the tac promoter by the Lac repressor which was assayed with the $x y l E$ gene from Pseudomonas putida as a marker gene. The $l a c I^{q}$ gene, transcribed by the strong spo promoter, allowed full repression of the weak tac promoter.

\section{INTRODUCTION}

A number of proteins produced by genetic engineering techniques are detrimental to cell growth. These problems can be overcome by the use of either chemically inducible or thermoinducible expression systems. Yansura \& Henner (1983) adapted the lac operatorrepressor system to achieve IPTG-inducible expression of interferon in Bacillus subtilis. Another approach is to use a promoter-repressor system from phage $\phi 105$. The repressor itself may be temperature-sensitive (Osburne et al., 1985) or its gene can be placed on a plasmid temperaturesensitive for replication (Dhaese et al., 1984); in other words, the repression can be relieved by incubation at a non-permissive temperature. In these thermoinducible systems the expression of cloned genes can be repressed only about 30 -fold while a chemically inducible system is repressed no more than 100 -fold.

Utilizing the well-characterized lac repressor-operator system, which operates in $B$. subtilis (Yansura \& Henner, 1983), we have developed an expression system regulated at the level of transcription. The use of the weak tac promoter (Moran et al., 1982; Peschke et al., 1985) should allow a high repression and, therefore, avoid interference with cell growth.

\section{METHODS}

Bacteria. Bacillus subtilis strain PSLl (Ostroff \& Pène, 1983) and Escherichia coli strain HB101 (Boyer \& Roulland-Dussoix, 1969) were used.

Ty broth for B. subtilis (Rottländer \& Trautner, 1970) and L broth for E. coli (Luria \& Burrous, 1957) were used throughout both as liquid and solid medium. The media were supplemented either with ampicillin $\left(50 \mu \mathrm{g} \mathrm{ml}^{-1}\right)$, neomycin $\left(5 \mu \mathrm{g} \mathrm{ml}^{-1}\right)$ or phleomycin $\left(0 \cdot 1 \mu \mathrm{g} \mathrm{ml}^{-1}\right)$.

Plasmids. pKK223-3 (Brosius \& Holy, 1984), placla (Bagdasarian et al., 1983), pTG402 (Zukowski et al., 1983) and pUB1 10 (Lacey \& Chopra, 1974) were used. Genes encoded by pUB110 are kan and ble (conferring Nm ${ }^{R}$ and $\mathrm{Pm}^{\mathrm{R}}$, respectively) and repU, the replication initiator protein (unpublished results).

Recombinant DNA procedures. Restriction endonucleases and DNA modification enzymes were purchased from Boehringer and used as described by the manufacturer.

Transformation. E. coli cells were transformed as described by Cohen et al. (1972). Transformation of competent B. subtilis cells was done as described previously (Rottländer \& Trautner, 1970).

Catechol 2,3-oxygenase assay. This was done essentially as described by Zukowski et al. (1983). Cell cultures were grown to an $\mathrm{OD}_{560}$ of 0.2 units; if required, IPTG was added and cells were further incubated for $120 \mathrm{~min}$. All values reported are the mean of four independent experiments with SE values within $15 \%$.

Abbreviation: IPTG, isopropyl $\beta$-D-thiogalactopyranoside. 
Dot blot analysis. RNA was isolated from E. coli and from B. subtilis by the methods of Brosius et al. (1982) and Sarachu et al. (1980) respectively. Dot blotting was done essentially as described by Thomas (1980); a nylon membrane (GeneScreen) was used instead of nitrocellulose. For nick-translation the PstI-BamHI fragment from pEB 113 containing the $x y l E$ gene was chosen.

\section{RESULTS AND DISCUSSION}

To construct a shuttle vector which is able to replicate and express a selectable marker in $E$. coli and $B$. subtilis, parts of pKK223-3 and pUB110 were fused. The pBR322-based plasmid, pKK223-2, was digested completely with $P v u I I$ and partially with BamHI to delete the truncated tet gene. From pUB1 10 the large EcoRI-PvuII fragment was used. Cohesive ends were filled in and ligation of both fragments resulted in plasmid pEB111, which confers $A^{R}, N^{R}$ and $P^{R}$ in $E$. coli and $\mathrm{Nm}^{\mathrm{R}}$ and $\mathrm{Pm}^{\mathrm{R}}$ in B. subtilis (Fig. 1). This vector comprises the entire expression device of pKK223-3, i.e. the tac promoter followed by the M13mp8-derived multicloning site and two tandemly ordered transcriptional terminators that work both in E. coli and in B. subtilis. Truncation of the pBR322 rom gene (see Tomizawa \& Som, 1984) in pEB1 11 causes an increased copy number in $E$. coli as compared to the wild-type (data not shown). The $1.1 \mathrm{~kb} E c o \mathrm{RI}$ fragment carrying the $l a c I^{9}$ gene (Bagdasarian et al., 1983) was placed downstream of a strong promoter derived from the B. subtilis bacteriophage SPO2 (spo) (Williams et al., 1981), and this construct was subsequently cloned into the unique $P v u I I$ site of $\mathrm{pEB} 111$. The resulting plasmid was named pEB112 (Fig. 1).

To show that the shuttle vector provides an appropriate tool for an inducible gene expression we chose the $x y l E$ gene from Pseudomonas putida as a marker gene. The $x y l E$ gene was recovered on a $1.9 \mathrm{~kb}$ fragment by digesting pTG 402 completely with BamHI and partially with $S a I I$. This fragment was cloned into the unique $B a m H I$ and $S a l$ restriction sites of the multicloning site in $\mathrm{pEB} 111$ or $\mathrm{pEB} 112$. Plasmid derivatives of $\mathrm{pEB} 111$ and $\mathrm{pEB} 112$ expressing the $x y / E$ gene were named $\mathrm{pEB} 113$ and $\mathrm{pEB} 114$ respectively.

To evaluate the activity of the tac promoter in the shuttle vector plasmids the tac promoter in pEB114 was deleted (pEB104) or replaced by the constitutively expressed spo promoter (pEB4). The first step was performed by replacing the $E c o$ RI- $B g I I I$ fragment from pEB114 containing the tac promoter by the $E c o \mathrm{RI}-B g / \mathrm{II}$ fragment from pUB 110 to create plasmid pEB 104 which is identical to pEB114 except for the tac promoter. Plasmid pEB4 was derived from pEB 114 by inversion of the EcoRI fragment comprising the pUB110 moiety and concomitant deletion of the smallest $E c o$ RI fragment containing the $l a c I^{q}$ gene so that the $x y l E$ gene is transcribed by the spo promoter.

The catechol 2,3-oxygenase activities obtained with these plasmids in E. coli and B. subtilis are listed in Table 1. Comparing the $x y l E$ expression of plasmids pEB113 and pEB4 we infer that in $E$. coli the tac promoter is slightly stronger than the spo promoter. The plasmid pEB114 bearing

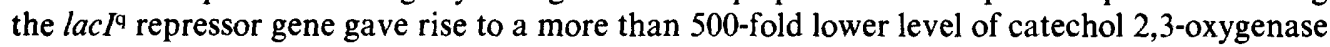
activity compared with an homologous plasmid (pEB113) lacking the repressor gene. The addition of IPTG to a final concentration of $1 \mathrm{mM}$ increased the expression of the $x y l E$ gene 330fold. Higher concentrations of IPTG did not show any further increase (data not shown). In $E$. coli the control plasmid lacking the tac promoter, pEB104, shows an 8-fold higher level of enzyme activity than plasmid pEB114 carrying the tac operator region. This increase was attributed to upstream promoters. In other words, the operator not only hinders the entrance of RNA polymerase but also may block transcriptional readthrough. This second mode of action, the termination of transcription at or near the operator site by the repressor, was recently reported by Deuschle et al. (1986).

The enzyme activities obtained with these vectors in $B$. subtilis were, in general, lower than in $E$. coli. Even for the strong $B$. subtilis spo promoter the values obtained were about two orders of magnitude lower. This lower expression of the $x y l E$ gene in $B$. subtilis allows a better distinction of different states of regulation. The regulation of gene expression, however, works as well as in $E$. coli, as shown by the at least 180 -fold increase in the specific enzyme activity in cells containing pEB114 after the addition of IPTG (1 mM). 

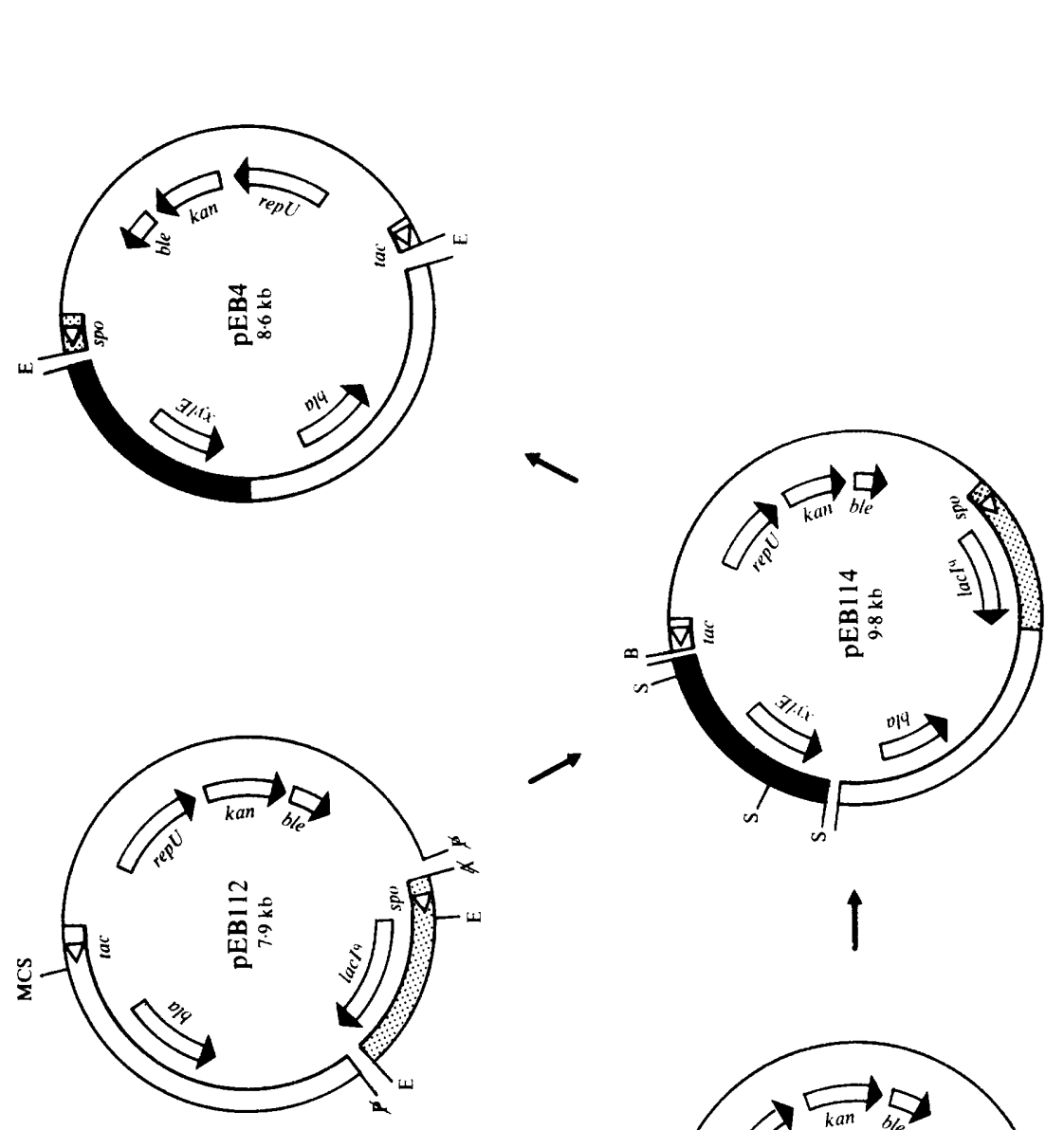

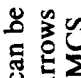

矛运

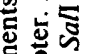

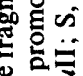

ำ

政

象范

范范

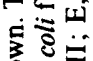

的路

틍

这

कo

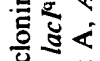

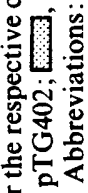

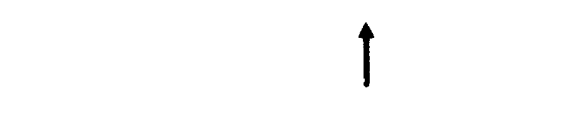

这它

啇舫

ปิ.
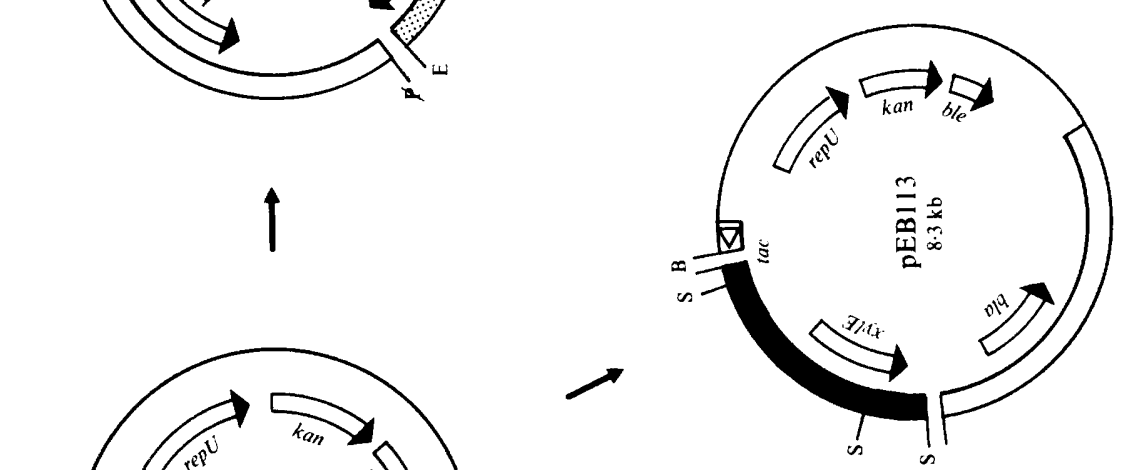

늠

行

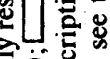

ธิ을

品要要

응전

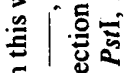

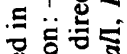

옹응

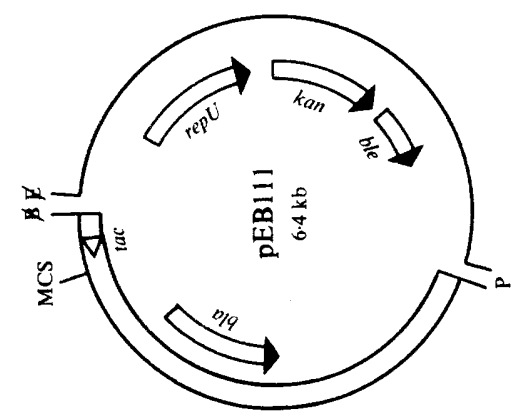

吾息

这志

कै

造

总的

능 矛

官昰造

.

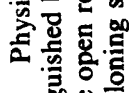

- - 哭苛

里产导 


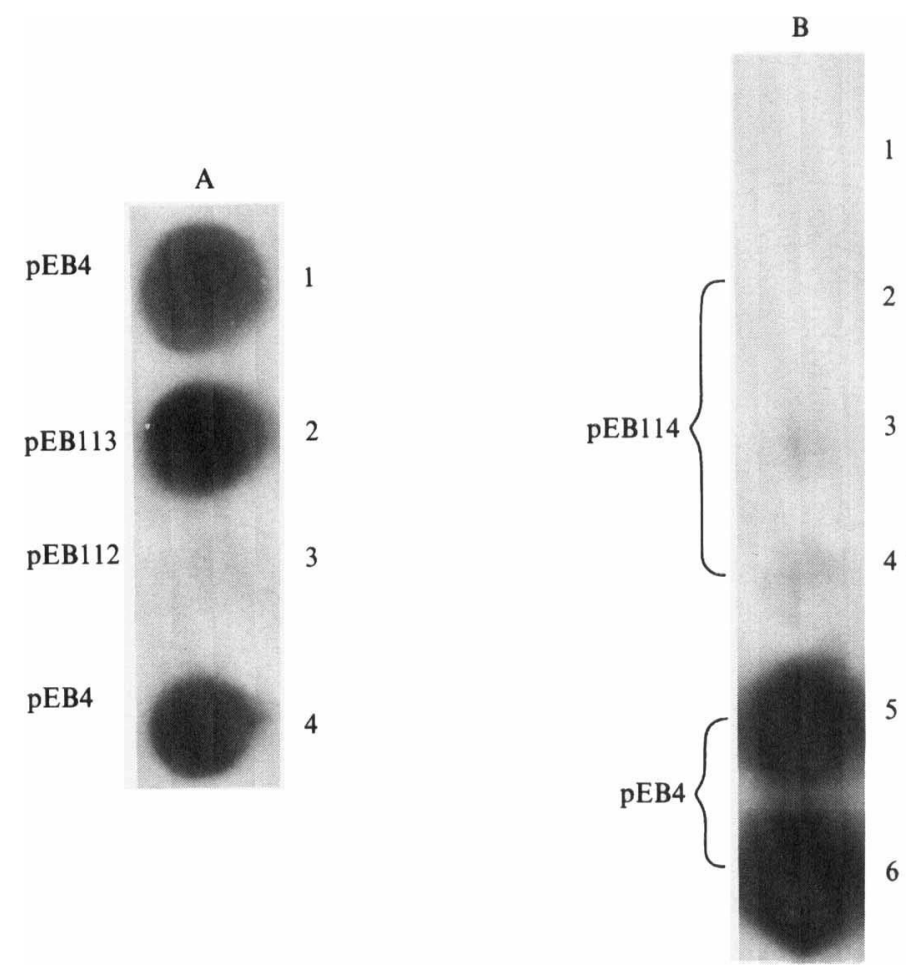

Fig. 2. Determination of specific $x y l E$ transcripts in $E$. coli and B. subtilis. Both E. coli and B. subtilis total RNA $(10 \mu \mathrm{g}$ per sample) were blotted onto a nylon membrane and hybridized to $0 \cdot 1 \mu \mathrm{g}$ of nicktranslated DNA with a total activity of $5 \times 10^{6}$ Cerenkov counts $\mathrm{min}^{-1}$. RNAs were isolated from $B$. subtilis PSL1 except for samples A1, A2 and A3 which were isolated from E. coli HB101. Cells in B3 and B4 were induced with $1 \mathrm{mM}-\mathrm{IPTG}$. B3/B4 and B5/B6 represent identical samples from independent experiments. B1 represents a plasmid-free control.

Table 1. Catechol 2,3-oxygenase activities

\begin{tabular}{|c|c|c|c|c|c|}
\hline \multirow[b]{2}{*}{ Plasmid } & \multirow[b]{2}{*}{ Promoter } & \multirow[b]{2}{*}{ Repressor } & \multirow{2}{*}{$\begin{array}{l}\text { IPTG } \\
(\mathrm{mM})\end{array}$} & \multicolumn{2}{|c|}{$\begin{array}{l}\text { Specific enzyme activity } \\
\left(\text { milliunits } \mathrm{mg}^{-1}\right)\end{array}$} \\
\hline & & & & E. coli $\mathrm{HB} 101$ & B. subtilis PSL1 \\
\hline pEB 113 & $t a c$ & - & $-*$ & 14000 & $2 \cdot 5$ \\
\hline $\mathrm{pEB} \perp 14$ & tac & + & 0 & 24 & $0 \cdot 005$ \\
\hline pEB 114 & $t a c$ & + & $0 \cdot 25$ & 6700 & $0 \cdot 6$ \\
\hline pEB 114 & $t a c$ & + & 0.5 & 7250 & $1 \cdot 06$ \\
\hline pEB 14 & tac & + & 1 & 8000 & 1.07 \\
\hline pEB4 & spo & - & $-^{*}$ & 11000 & 110 \\
\hline pEB 104 & - & + & $-*$ & 200 & 0.005 \\
\hline
\end{tabular}

* Identical results were obtained after addition of 1 mM-IPTG.

In $B$. subtilis the tac activity measured under repressed conditions (pEB114 without addition of IPTG) was not distinguishable from the background level of enzyme activity found in plasmid free strains.

To verify that regulation takes place at the level of transcription and to investigate the reasons for the low expression of the $x y l E$ gene in $B$. subtilis we determined the relative amount of specific $x y l E$ mRNA by dot blot analysis. The comparison between $E$. coli and $B$. subtilis in Fig. 2 shows that the amount of specific mRNA produced with the spo promoter is of the same order of magnitude in both species, suggesting that the host difference in the catechol assay is post- 
transcriptional. In $B$. subtilis we failed to detect specific $x y l E$ mRNA transcribed from the $t a c$ promoter under repressed conditions (Fig. 2B).

Derepression of these cultures with IPTG $(1 \mathrm{~mm})$ however, gave rise to detectable specific transcripts (about $8 \%$ of what was found for the spo promoter). This is in good agreement with results reported by Peschke et al. (1985).

The high repressibility should make this shuttle vector an appropriate tool for expressing genes which are detrimental to cell growth. Replacing the weak tac promoter by the related trc promoter, which is reported to belong to the strong B. subtilis promoters (Osburne \& Craig, 1986), should adapt this vector for purposes which require higher expression.

We are grateful to T. A. Trautner for critical reading of the manuscript and continuous interest in this project. We are indebted to $P$. Ceglowski and $C$. Nawrath for constructing some plasmid intermediates.

\section{REFERENCES}

Bagdasarian, M. M., Amann, E., Lurz, R., RückERT, B. \& Bagdasarian, M. (1983). Activity of the hybrid trp-lac (tac) promoter of Escherichia coli in Pseudomonas putida. Construction of broad-hostrange, controlled-expression vectors. Gene 26, 273282.

BOYER, H. W. \& Roulland-Dussoix, D. (1969). A complementation analysis of the restriction and modification of DNA in E. coli. Journal of Molecular Biology 41, 459-472.

BRosius, J. \& Holy, A. (1984). Regulation of ribosomal RNA promoters with a synthetic lac operator. Proceedings of the National Academy of Sciences of the United States of America 81, 6929-6933.

Brosius, J., Cate, R. L. \& Perlmutter, A. P. (1982). Precise location of two promoters for the $\beta$ lactamase gene of pBR322. Journal of Biological Chemistry 257, 9205-9210.

Cohen, N. S., Chang, A. C. Y. \& Hsu, L. (1972). Nonchromosomal antibiotic resistance in bacteria: genetic transformations of Escherichia coli by Rfactor DNA. Proceedings of the National Academy of Sciences of the United States of America 69, 21102114.

Deuschle, U., GenTz, R. \& BujaRd, H. (1986). lac repressor blocks transcribing RNA polymerase and terminates transcription. Proceedings of the National Academy of Sciences of the United States of America 83, 4134-4137.

Dhaese, D., Hussey, C. \& Van Montagu, M. (1984). Thermoinducible gene expression in Bacillus subtilis using transcriptional regulatory elements from temperate phage $\phi 105$. Gene 32, 181-194.

LACEY, R. W. \& CHOPRA, I. (1974). Genetic studies of a multiresistant strain of Staphylococcus aureus. Journal of Medical Microbiology 124, 597-601.

Luria, J. \& Burrous, J. W. (1957). Hybridization between E. coli and Shigella. Journal of Bacteriology 74, 461-476.

Moran, C. P., Lang, N., LeGrice, S. F. J., Lee, G., Stephens, M., Sonenshein, A. L., Pero, J. \& LosICK, R. (1982). Nucleotide sequence that signals the initiation of transcription and translation in Bacillus subtilis. Molecular and General Genetics 186, 339-346.

OSBURNe, M. S. \& CRAIG, R. J. (1986). Activity of two strong promoters cloned into Bacillus subtilis. Journal of General Microbiology 132, 565-568.
Osburne, M. S., Craig, R. J. \& Rothstein, D. M. (1985). Thermoinducible transcription system for Bacillus subtilis that utilizes control elements from temperate phage $\phi 105$. Journal of Bacteriology 163, 1101-1108.

OSTROFF, G. R. \& PÈnE, J. J. (1983). Molecular cloning with bifunctional plasmid vectors in Bacillus subtilis: isolation of a spontaneous mutant of $B$. subtilis with enhanced transformability for $E$. coli-propagated chimeric plasmid DNA. Journal of Bacteriology 156, 934-936

Peschke, U., Beuck, V., Bujard, H., Gentz, R. \& LEGRICE, S. (1985). Efficient utilization of Escherichia coli transcriptional signals in Bacillus subtilis. Journal of Molecular Biology 186, 547-555.

RotTländer, E. \& Trautner, T. A. (1970). Genetic and transfection studies with Bacillus subtilis phage SP50. 1. Phage mutants with restricted growth on $B$. subtilis strain 168. Molecular and General Genetics 108, 47-60.

Sarachu, A. N., Alonso, J. C. \& Grau, O. (1980). Novobiocin blocks the shut off of SPO1 early transcription. Virology 105, 13-18.

Thomas, P. S. (1980). Hybridization of denatured RNA and small DNA fragments transferred to nitrocellulose. Proceedings of the National Academy of Sciences of the United States of America 77, 52015205.

Tomizawa, J. \& Som, T. (1984). Control of ColEl plasmid replication: enhancement of binding of RNA I to the primer transcript by the Rom protein. Cell 38, 871-878.

Williams, D. M., Duvall, E. J. \& Lovett, P. S. (1981). Cloning restriction fragments that promote expression of a gene in Bacillus subtilis. Journal of Bacteriology 146, 1162-1165.

Yansura, D. G. \& Henner, D. (1983). Use of the Escherichia coli lac repressor and operator to control gene expression in Bacillus subtilis. Proceedings of the National Academy of Sciences of the United States of America 81, 439-443.

Zukowski, M. M., Gaffney, D. F., SPECK, D., KauffManN, M., Findell, A., Wisecup, A. \& LECOCQ, J.-P. (1983). Chromogenic identification of genetic regulatory signals in Bacillus subtilis based on expression of a cloned Pseudomonas gene. Proceedings of the National Academy of Sciences of the United States of America 80, 1101-1105. 